\title{
A Construção do Mercado Solidário Brasileiro: contribuição das redes de Economia Solidária
}

\author{
Ivette Tatiana Castilla Carrascal \\ Orientador: Christiane Girard Ferreira Nunes \\ Dissertação de Mestrado \\ Data da defesa: 11.11.2011
}

$\mathrm{E}$ sta dissertação trata da construção do mercado solidário brasileiro, a partir das contribuições das redes de Economia Solidária. O objetivo foi compreender e analisar as contribuições que as redes fazem à construção de um mercado solidário no Brasil e identificar quais os efeitos, as mudanças vivenciadas no interior dos empreendimentos que fazem parte das mesmas redes. Para esse fim, procuramos caracterizar e analisar as Redes Bodega, ACS Amazônia, Rede Ecovida, Central do Cerrado e Justa Trama, mostrando quais os empreendimentos que as constituem, quais os fluxos que as perpassam, quais suas práticas de comércio justo e solidário e os desafios enfrentados, entre outras questões. No primeiro capítulo, apresentamos as diferentes concepções de mercado e sua evolução no tempo, para, então, nos determos às suas desigualdades e assimetrias no século XX. Faz-se também uma contextualização do momento atual que passa o Brasil com as iniciativas no campo do Comércio Justo, onde a sociedade civil organizada e Estado dialogam sobre o Sistema Nacional de Comércio Justo e Solidário. No segundo capítulo, fazemos uma discussão sobre as diferentes características das redes nas teorias sociais mais gerais e sobre as redes no campo da Economia Solidária ou de colaboração solidária. Ainda nesse capítulo, analisamos algumas afirmações sobre as razões de se organizar em rede, com uma discussão introdutória sobre a Teoria do Ator-Rede, lente teórica utilizada para a análise do objeto de pesquisa deste trabalho. As observações realizadas no campo empírico nos levam a considerar que as redes de Economia Solidária fortalecem a sua identidade mediante diferentes práticas, dentre as quais as relacionadas a princípios do comércio justo e solidário. Fortalecem vínculos sociais entre os grupos, os acordos comerciais que se estabeleceriam com base nesses princípios e isso, por sua vez, favoreceria a articulação entre os atores. Além disso, para tentar dar conta da sustentabilidade econômica das redes, seria preciso que desenvolvessem algumas práticas de planejamento, implementação e controle dos seus fluxos em rede e, assim, ampliasem as possibilidades de elevação da renda, de melhorar os intercâmbios comerciais e de criar e fortalecer espaços alternativos de comercialização

Palavras-chave: Economia Solidária, Redes de Economia Solidária, Comércio Justo, Comércio Justo e Solidário, Mercado Solidário. 